OPEN ACCESS

Approved by:

Frontiers in Neuroscience Editorial Office,

Frontiers Media SA, Switzerland

*Correspondence:

Qingguo $\mathrm{Ma}$

maqingguo3669@zju.edu.cn

Linanzi Zhang

bnunanzi@163.com

tThese authors have contributed equally to this work

Specialty section

This article was submitted to

Neural Technology,

a section of the journal

Frontiers in Neuroscience

Received: 12 February 2019

Accepted: 13 February 2019

Published: 05 March 2019

Citation:

Ma Q, Zhang L and Wang M (2019)

Corrigendum: "You Win, You

Buy"-How Continuous Win Effect

Influence Consumers' Price

Perception: An ERP Study.

Front. Neurosci. 13:167.

doi: 10.3389/fnins.2019.00167

\section{Corrigendum: "You Win, You Buy"-How Continuous Win Effect Influence Consumers' Price Perception: An ERP Study}

\author{
Qingguo Ma ${ }^{1,2,3,4 * t}$, Linanzi Zhang ${ }^{1,5 * t}$ and Manlin Wang ${ }^{1}$ \\ ${ }^{1}$ School of Management, Zhejiang University, Hangzhou, China, ${ }^{2}$ Institute of Neuromanagement Science, Zhejiang University \\ of Technology, Hangzhou, China, ${ }^{3}$ Business School, Ningbo University, Ningbo, China, ${ }^{4}$ Academy of Neuroeconomics and \\ Neuromanagement, Ningbo University, Ningbo, China, ${ }^{5}$ School of Management, Guizhou University, Guiyang, China
}

Keywords: continuous win effect, price perception, event-related potentials, P2, P300, LPP, neuromanagement, neuromarketing

\section{A Corrigendum on}

"You Win, You Buy"-How Continuous Win Effect Influence Consumers' Price Perception: An ERP Study

by Ma, Q., Zhang, L., and Wang, M. (2018). Front. Neurosci. 12:691. doi: 10.3389/fnins.2018.00691

There is an error in the Funding statement. The correct number for the "National Project" is "AWS14J011".

The authors apologize for this error and state that this does not change the scientific conclusions of the article in any way. The original article has been updated.

Copyright (c) $2019 \mathrm{Ma}$, Zhang and Wang. This is an open-access article distributed under the terms of the Creative Commons Attribution License (CC BY). The use, distribution or reproduction in other forums is permitted, provided the original author(s) and the copyright owner(s) are credited and that the original publication in this journal is cited, in accordance with accepted academic practice. No use, distribution or reproduction is permitted which does not comply with these terms. 